$\begin{array}{cccc}S \text { sciendo } & \text { International Conference KNOWLEDGE-BASED ORGANIZATION } \\ \text { Vol. XXV } & \text { No } 2 & 2019\end{array}$

\title{
INITIATION/COMMENCEMENT OF CRIMINAL PROSECUTION IN THE NEW CRIMINAL PROCEDURE CODE
}

\author{
Fănică CERCEL \\ University of Bucharest, Bucharest, Romania \\ fanicacercel@yahoo.com
}

\begin{abstract}
The initiation of criminal prosecution is always preceded by the notification of criminal investigation bodies (or the disclosure) about the commission of a crime, since it is not possible to start the criminal trial in the absence of such notification. Another (negative) condition is the nonexistence of any of the cases provided by art. 16 of the Criminal Procedure Code, otherwise they are closed prior to the commencement of criminal prosecution.The procedural act by which the prosecution is initiated, according to Article 305, paragraph 2, of the Criminal Procedure Code is the ordinance. The commencement of criminal prosecution is always ordered in respect of the offense, even if the person who committed the offense is indicated in the notice.
\end{abstract}

Keywords: criminal prosecution, referral, criminal trial, ordinance, criminal prosecution body

\section{Introduction}

The commencement of criminal prosecution is an important criminal procedural institution, which marks the initial moment of criminal prosecution, the moment when the criminal proceedings start, representing the establisment of the legal framework for the exercise of procedural rights and obligations.

The criminal trial has four stages: criminal prosecution (which takes place in terms of the offence immediately after the referral, and then on the person), the preliminary hearing, the trial (at the first instance and, afterwards, possibly on appeal) and the execution of the final court decision.

Criminal prosecution is the first stage of criminal trial and is designed to prepare and ensure the proper conduct of the criminal trial at the trial stage, through the detection of crimes, identification and capture of the offenders to be tried, gathering evidence on the offense and the perpetrator, so that the offense committed and the person to be tried, as well as the other persons who may have a procedural capacity in question, are known at the time of the court's referral.

According to the current regulation, criminal prosecution is a judicial function (art. 3), which is exercised ex officio, unless otherwise stipulated by law, and in its exercise the prosecutor and the criminal investigation bodies collect the necessary evidence to it so to establish whether or not there are grounds for referral.

\section{Conditions}

In view of the significance of this procedural act, which produces important consequences, the conditions and the form in which the initiation of the criminal investigation materialize are regulated in detail. 
From the interpretation of the provisions of art. 305 of the Criminal Procedure Code, there are cumulative conditions necessary for the commencement of criminal prosecution, a positive one and a negative one:

- the existence of a criminal investigation body referral/notice, which may be external (complaint, denunciation, etc.), internal (ex officio referral) or made by special means (prior complaint, notification to the competent body), containing a minimum of data or information on which to initiate the prosecution;

- it is found that there is none of the cases that prevent the criminal action provided by art. 16, paragraph 1, of the Criminal Procedure Code.

The conditions are cumulative and, once fulfilled, the competent criminal investigation body is compelled to initiate prosecution, as the new Criminal Procedure Code no longer regulates the stage of the preliminary acts, so that when the referral meets the formal and substantive conditions and does not exist one of the cases that prevent the criminal proceedings, it will be ordered to start criminal prosecution.

Each of these conditions requires careful consideration because, if they are not met, in the absence of the precursor acts provided for in the old regulation, criminal prosecution can not be initiated, being ordered the closing of the case (Article 315).

As a practical matter, with the entry into force on February 1, 2014 of the new Criminal Procedure Code, in all criminal files registered in the prosecutor's offices, which were at the stage of preliminary acts and in which the conditions for starting the criminal prosecution were met, the criminal prosecution of the offence committed was commenced, thus creating the criminal procedural framework required by the new regulation.

\subsection{Referral modes}

The commencement of criminal prosecution is always preceded by the notification of the criminal investigation bodies (or the disclosure) of the commission of a crime.
The legal way by which the judicial body is informed about the commission of a crime is the act of referral, having the effect of investituring the criminal prosecution body and creating the legal framework for carrying out this procedural activity. Referral to the judicial bodies is the starting point of the criminal prosecution, without which it can not begin, and contains both the information element and the legal basis for starting the legal research activity.

Although there are no express provisions in the Criminal Procedure Code, the doctrine has divided the referral modes into several categories:

a) External referral (complaint, denunciation, prior complaint, etc.) and internal (legal self-enforcement or ex officio referral);

b) Primary referral (represents an absolute novelty, which first comes to the attention of a criminal prosecution body) and complementary (with secondary character, being subsequent to the primary referral); ;

c) General ways of referral (ordinary means of referral, equal in importance, with the consequence that they can be supplemented) and special means of referral (exclusive character, criminal prosecution can not be carried out without them).

In the previous Criminal Procedure Code, special referrals were absolute conditions for initiation of criminal prosecution, but in the current regulation, their absence hinders the conduct of criminal proceedings, not the initiation of prosecution [1].

Regarding the ways of referral, art. 288 of the Law no. 135/2010 kept the ones enshrined in the previous regulation:

1. The criminal investigative body is notified by complaint or denunciation, by the acts concluded by other law enforcement bodies or by ex officio.

2. When, according to the law, the criminal prosecution can be initiated only upon preliminary complaint of the injured person, at the request made by the person stipulated by the law or with the authorization of the body stipulated by the 
law, the criminal action can not be carried out in the absence thereof.

Paragraph 3 was added, which stipulates that in the case of crimes committed by soldiers, the commander's referral is only necessary in respect of the offenses referred to in Articles 413 - 417 of the Criminal Code.

It can noy be found in the new C.P.C. the provisions regarding the expression of the will of a foreign state and the situation of the offenses whereby a damage occurred to a unit out of those provided by art.145 existing in the old regulation (previous Criminal Procedure Code).

\subsection{Complaint}

According to art. 289, paragraph 1 of Criminal Procedure Code, the complaint is the notification made by an individual or a legal person regarding a prejudice caused by a crime.

The complaint, as a means of referral to the criminal prosecution bodies, should not be confused with the prior complaint, which is also a condition of punishment and procrastination. The absence of a prior complaint can not be remedied by other means of referral, whereas an ordinary criminal complaint may be replaced by a notice or an ex officio referral.

The complaint must include the name, surname, personal numeric code, the quality and domicile of the petitioner, the description of the deed which is the subject of the complaint, as well as the indication of the perpetrator and the means of evidence, if known.

The complaint may be made in writing (including electronically) or orally (including by calling SNUAU 112), in which case it is recorded in a minutes, and is optional, remaining at the discretion of the injured party if he or she formulates it or not.

As an element of novelty, art. Article 289 (para. 2) provides that for legal persons the complaint must include the name, the registered office, the unique registration code, the fiscal identification code, the registration number in the trade register or the registration of the legal entities and the bank account, the indication of the legal or conventional representative .

New items are also provided in paragraphs 4 and 5 regarding the obligation to sign the complaint by the injured party or the trustee and the conditions of the complaint in electronic form:

"(4) If it is made in writing, the complaint must be signed by the injured person or by the trustee.

(5) Complaint in electronic form fulfills the form conditions only if it is certified by electronic signature in accordance with the legal provisions. "

The complaint may be made personally, by trustee with a special mandate (the proxy remains attached to the complaint) or by a procedural substitute (the spouse for the other spouse or the major child for his parents), but the injured person may declare that he does not accept the complaint, and, when done orally, it shall be recorded in a minutes by the receiving body.

For persons without legal capacity, the complaint is made by the legal representative, and in the case of persons with limited legal capacity, the referrals are formulated by them, with the consent of the persons provided by the civil law, except when the perpetrator is a legal representative or is responsible for the acts of the injured person, or when the notification of the criminal investigation bodies is done ex officio.

A special situation concerns criminal offenses committed outside the territory of Romania when the complaint filed with the Romanian judicial body by the injured party, resident in Romania, is transmitted directly or, in the case of non-member states of the European Union, through the central judicial authorities, to the competent foreign authorities of the State in whose territory the crime was committed [2].

\subsection{Denounced}

According to art. 290 of the Criminal Procedure Code, the denunciation is the notification made by a natural person or by 
a legal person about the commission of a crime and, as well as the complaint, presents the same legal characters - being an external, general, primary and principal external referral.

Denunciation is an optional way of reporting a crime to criminal investigation bodies, and people have no legal obligation to do so.

However, if the law provides for the legal obligation to denounce certain offenses, in this case the denunciation is mandatory, the non-referral representing an offense (Article 266 of the Criminal Code). Otherwise, the law provides that some persons with management positions should refer the judicial bodies about the commission of a crime, in which case this is a special way of referral.

According to the provisions of art. 291 of the Criminal Procedure Code, the notification of the criminal investigation bodies is mandatory for any person with a leading position within a public administration offive or other public authorities, as well as for any persons with control tasks who, in the exercise of their duties, have become aware of the commission of an offense.

Similarly, the same obligation applies to any person exercising a service of public interest for which he has been entrusted by the public authorities or is under their control or supervision, who, in the exercise of his duties, has become aware of the commission of an act provided for by the criminal law, an obligation concerning only the offenses for which the criminal action is initiated ex officio.

In some cases, the law provides that the denunciation can be done by the person who committed the offense (selfdenunciation), and such denunciations lead either to the removal of criminal liability or to the alleviation of this liability. For example, according to Article 290, para. 3, of the Penal Code, the briber is not punished if he denounces the crime to the authority before the criminal prosecution body is notified of the offense of bribery.

Unlike the previous regulation, art. 290, paragraph 2, provides that the denunciation may be made only personally, the provisions of art. 289 par. 2, $4-6$ and $8-$ 10, applying accordingly (novelty in paragraphs 4 and 8) [3].

As well as the complaint, in view of the consequences it may cause (including the attribution of the criminal responsibility to the offender when it does not correspond to reality), the denunciation must be assumed by signing it, when made in writing, or by certifying the identity of the denouncer in the minutes in which is recorded, when formulated orally [4].

\subsection{Modes of special referral}

The special ways of referral can not be supplemented by other means, general or special, and the ex officio referral being excluded as well and must be made in writing and signed by the competent body, including the content items provided for the complaint.

In this category can be classified as example, the referral made by the commander of the military unit (for the offenses referred to in art.413-417 of the Penal Code, committed by the soldiers), the commander's referral, the complaint of the owner or the operator of the ship in the case of some offenses stipulated in the Law no. $191 / 2003$, or the notification of the Chamber of Commerce and Industry or of persons authorized by the Competition Council in the case of unfair competition offenses, according to art. 8 of the Law no.11 / 1991.

These special ways of referral should not be confused with the authorization of the body provided by the law (authorization of the General Prosecutor of the Prosecutor's Office attached to the Court of Appeal or the High Court of Cassation and Justice for the offenses committed under the conditions of Articles 8 and 9 of the Penal Code, authorization of the Senate, the Chamber of Deputies or the President of 
Romania to start criminal prosecution against the members of the government), which is a prerequisite for starting and conducting criminal prosecution.

Also, while the absence of the special referral prevents the prosecution, certain pre-requisites, necessary for carrying actually out some criminal procedural acts (the authorization for arrest, arrest or search by the Chamber of which they belong to the MPs, or by the appropriate section of the SCM in the case of judges and prosecutors) does not prevent criminal prosecution [5]. In the current Criminal Procedure Code, the ambiguous phrase in the old regulation (the unit referred to in Article 145 of the Criminal Code) has been replaced and the obligation to refer to offenses for which the criminal action is initiated ex officio has been reduced [6].

The concept of civil servant has been defined and the obligation to refer to offenses for which the criminal prosecution is automatically initiated is reduced, being eliminated the condition that the offense must be related to the service.

Among the special referrals, the preliminary complaint has a distinct regulation, the procedure of which is provided by art. 295298 of the Criminal Procedure Code, but does not trigger a special procedure of prosecution and trial in the cases in which it is formulated.

The significance of this type of referral results not only from the impossibility of initiating criminal prosecution, but also from the effects it produces in the course of the criminal proceedings, which can be stopped by reconciling the parties, withdrawing the preliminary complaint or concluding a mediation agreement.

The institution of the preliminary complaint has a dual legal nature, being as a special means of referral from procedural perspective, a mandatory condition for initiating and conducting criminal prosecution and, from a substantive point of view, it is a necessary condition for the criminal indictment of the investigated persons, the lack of this being a cause that removes criminal liability.

The right to make a preliminary complaint lies with the injured person, namely the individual or legal person who has suffered physical, material or moral damage by the commission of the criminal offense, which has therefore a personal, indivisible and non-transferable character.

It may be formulated in person or by a trustee (with a special mandate attached to the complaint), and in the case of minors and incapacitated persons (lack of legal capacity) by the legal representative, but as second option, in this case, the criminal prosecution may be initiated ex officio (art. 154, paragraph 4 of Criminal Procedure Code).

Also, if the injured person is deprived of his or her legal capacity or has limitedlegal ability, or a legal person, represented by the perpetrator himself, the criminal prosecution is also set in motion ex officio.

The personal nature of prior complaint relates not only to the claimant, but also to the person against whom it is formulated, which must be known by the injured person and indicated, with the express wording that he wishes to be prosecuted.

As regards form and content, the provisions of Article 289 para. 2 of the Penal Code are applicable, the major difference to the complaint being the time limit within which the preliminary complaint must be made, namely three months from the day the injured person learned about committing the deed, whether or no he knew who the perpetrator was at that time.

The current regulation is deficient in this respect; in cases where the perpetrator of the deed is discovered after the passing of the three months, he can not be held criminally liable, and we appreciate, de lege ferenda, that it would be necessary to amend Article 296 paragraph 1 of the Criminal Procedure Code, by adding the phrase "or when the injured person knew who the perpetrator is," as provided by art. 
284 para. 1 of the previous Criminal Procedure Code.

Like other procedural acts, the prior complaint wrongfully directed to the criminal investigative body or the court is sent, by administrative means, to the competent body, being considered valid if it was filed within the time limit with the incompetent body.

The period within which a prior complaint must be filed shall not be interrupted or suspended, even if the injured person was objectively unable to formulate it, the only exception being the duration of the mediation.

However, if the objective impossibility of formulating the prior complaint was determined by the commission of the offense, the commencement of the criminal prosecution and the pursuit of the prosecution during the three-month period may also be ordered ex officio [7].

Special issues concerning the prior complaint procedure:

- upon receipt of the preliminary/prior complaint, the criminal investigation body verifies whether it fulfills the formal conditions and whether it has been filed within the time limit prescribed by law (Article 297 (1) of the Criminal Procedure Code);

- in the case of a flagrant offense, the criminal investigation body is obliged to state its execution, after which the injured party is summoned to declare whether he or she intends to make a preliminary complaint or not, proceeding accordingly (Article 298 of the Criminal Procedure Code.)

- when a criminal prosecution has been carried out in one case and the preliminary complaint is found to be necessary, the criminal investigation body proceeds as in the previous case (Article 297 of the Criminal Procedure Code);

- if the court changes the legal framing of the offense for which the prosecution has been ordered in an offense for which the prior complaint is required, the injured person will be summoned and asked if he or she understands to make such a complaint (Article 386, paragraph 2 of the Criminal Procedure Code).

\subsection{Referralex officio}

It is an ex officio referral of the criminal prosecution bodies when they find out by any means necessary (other than the ones previously analyzed) about the commission of a crime, and it is done either by direct observation of the commission of criminal acts or by the means of mass information.

An ex officio referral may also have a subsidiary character in situations where another way of referral does not have its effects (anonymous denunciation, complaint without the data of the injured person, where the perpetrator is the legal representative of the person lacking legal ability, etc.), in which case it employs the legal form and the information contained in an inappropriate way of reporting is used legally, so that it materializes in a criminal record concluded by the criminal investigative body which is therefore legally invested with the settlement of the case.

It has a distinct regulation, compared to the previous Criminal Procedure Code, in Art. 292:

"The criminal investigative body refers ex officio if it finds out that a crime has been committed in any way other than those provided under art. 289-291 and conclude a report to that effect".

Even if the criminal investigative body directly finds out about the commission of an offense, it can not refer ex officio whether a prior complaintis necessary for that offense. In these situations, the criminal investigation body calls the injured person and asks if he or she make a complaint.

The report concluded after the ex officio referral are not an act of commencement of criminal prosecution (which must be ordered separately, by means of ordinance), but only the way in which the criminal prosecution bodies are notified. 
The simple referral of these organs is not sufficient to order the commencement of the criminal prosecution, those being compelled, upon the receipt of the complaint, to verify its competence, and if it finds that it is not competent to resolve the case, it shall submit it to the prosecutor, with the proposal to refer it to the competent body.

If the referral is addressed directly to the prosecutor, when ascertaining that he is not competent, either materially, territorially or by the quality of the person, to solve it, he shall send it to the competent prosecutor. It is not a matter of declining jurisdiction (the prosecuting authority is not legally notified), but sent by an administrative reference, a way considered in the doctrine as legally questionable (as an administrative measure) and objectionable from the point of view of regulation, since it overlaps with the ways of regulating competence, provided by art.58 of the Criminal Procedure Code [8].

In cases where the complaint or denunciation does not meet the requirements of form and substance stipulated by the law or the description of the act is unclear or incomplete, it shall be returned administratively to the petitioner, specifying the elements to be filled in.

However, if the referral fulfills the legal conditions, but from its contens results any of the cases preventing the criminal prosecution, stipulated in Article 16, paragraph 1 of the Criminal Procedure Code, it shall be forwarded to the prosecutor with a proposal for closing, otherwise the initiation of criminal prosecution will be ordered, and in both cases the referrals shall be recorded in the criminal records, and the prosecutor's office will assign a unique number to the file.

Art.294 of the Criminal Procedure Code stipulates that whenever a prior authorization or other precondition is required for the purpose of initiating criminal prosecution, the criminal investigative body is required to carry out prior verifications, which are not criminal prosecution acts, having extra-judicial character (being conducted prior to the commencement of the criminal proceedings), but are carried out for trial purposes, and no evidence can be given at this stage becausethe procedural safeguards guaranteeing the right to a fair trial would be avoided.

\subsection{Procedural act ordering the commencementof criminal prosecution}

According to art. 286, the prosecutor decides upon the procedural acts or measures and solves the case by ordinance, unless the law stipulates otherwise.

Article 305, paragraph 2, expressly provides that the commencement of the prosecution is ordered by an ordinance comprising (Article 286. paragraph 2. letters a-c and $\mathrm{g}$ ):

- name of the prosecutor's office and date of issue;

- the name, surname and the quality of the person submitting it;

- the offence which is the object of the criminal investigation, its legal classification and, where appropriate, the data concerning the person of the suspect or defendant;

- the signature of the person who drew it.

The ordinance for the initiation of criminal prosecution may be issued either by the prosecutor or by the criminal investigation body (not subject to a reasoned confirmation by the prosecutor as in the previous regulation) and may be appealed with a complaint to the prosecutor supervising the prosecution or the hierarchically superior prosecutor, under the conditionsof Art.336-339 of the Criminal Procedure Code.

A special situation regarding the commencement of criminal prosecution is the offense of audience when it comes to the way in which this procedural act is ordered.

As a general rule, the prosecution will be ordered by ordinance, following the refferal of the criminal prosecution body, by the 
conclusion of a hearing in which the offence provided by the criminal law was established and the perpetrator was identified.

In exceptional circumstances, when considering the manner of committing the offense or the person of the perpetrator, urgent action (including detention of the suspect or defendant) must be taken, the prosecution is initiated (in rem) by the oral statement of the prosecutor, which is recorded at the close of the meeting (art.360 paragraph 2 of the Criminal Procedure Code).

\section{Conclusions}

The procedural act of initiating the criminal prosecution "in rem" produces important legal consequences, triggering the criminal prosecution (and, implicitly, the criminal trial), the legal framework in which the investigations will be carried out,with evidence being given (such as picking up objects and documents, hearing people, conducting searches, supervising technical measures, etc.) etc.) or procedural acts or measures (order of sequester, retention of correspondence, seizure of accounts, etc.) being ordered.

\section{References}

[1] ZARAFIU, Andrei - Procedură penală. Partea generală. Partea specială. Ediţiaa II-a, Ed. C.H.Beck, Bucureşti, 2015, p.335.

[2] Art.127dinLegea nr. 302 / 2004, publicată în Monitorul Oficial al României, Partea I, nr. 377 din 31.05 .2011

[3] Art. 289 alin. 4 şi 8 C.pr.pen. „(4) If done in writing, the complaint must be signed by the injured person or the trustee.

[4] ZARAFIU, Andrei - Procedură penală. Partea generală. Partea specială. Edițiaa II-a, Editura C.H. Beck, Bucureşti, 2015, p.337.

[5] ZARAFIU, Andrei - Procedură penală. Partea generală. Partea specială. Edițiaa II-a, Ed. C.H.Beck, Bucureşti, 2015, p. 340.

[6] Art. 291, para. 2 of Criminal Procedure Code: „Any person performing a service of public interest for which he has been entrusted by the public authorities or who controls or oversees those persons on the performance of that public interest service, who, during the performance of his duties, has become aware of an offense for which the criminal prosecution is initiated ex officio, is obliged to immediately notify the criminal investigative body".

[7] UDROIU, Mihai - Procedură penală. Partea specială, ed. a-II-a, Ed.C.H.Beck, Bucureşti, 2015, p.25.

[8] ZARAFIU, Andrei - Procedură penală. Partea generală. Partea specială. Edițiaa II-a, Ed. C.H.Beck, Bucureşti, 2015, p.344. 